\title{
THE STUDY OF SERUM LIPID PROFILE IN PREGNANCY INDUCED HYPERTENSION IN JMC, JHALAWAR.
}

\author{
Dr. Nanu Ram Jat ${ }^{1}$, Dr. Ritu Gupta ${ }^{2}$, Dr. Ayushi Gupta ${ }^{3}$ \\ ${ }^{1}$ PG Resident of OBG in JMC Jhalawar, Rajasthan, India \\ ${ }^{2}$ HOD and Unit Head of Obstetrics and Gynaecology, Jhalawar Medical College, Jhalawar, Rajasthan, \\ India \\ ${ }^{3}$ Seth GS Medical College Mumbai, India
}

Article Info: Received 15 January 2019; Accepted 06 February. 2019

Cite this article as: Jat, D. N. R., Gupta, D. R., \& Gupta, D. A. (2019). CASE STUDY OF SERUM LIPID PROFILE IN PREGNANCY INDUCED HYPERTENSION IN JMC, JHALAWAR. Journal of Biomedical and Pharmaceutical Research, 8(1).

DOI: https://doi.org/10.32553/jbpr.v8i1.571

Address for Correspondence: Dr. Nanu Ram Jat, HOD and Unit Head of Obstetrics and Gynaecology, Jhalawar Medical College, Jhalawar, Rajasthan, India.

Conflict of interest statement: No conflict of interest

\section{ABSTRACT:}

Only one group was investigated for serum lipid profile in third trimester of pregnancy in which included all PIH patients admitted in labor room in Department of Obstetrics in Jhalawar Medical College and was substantially compared with the normal values of Lipids in women. In this study we investigate the role of lipid profile in PIH. LDL value increase, HDL value decrease, TG value increase and VLDL value increase in PIH patients and also TG: HDL ration increased significantly in PIH patients. Dyslipidemia mediated activation of endothelial cells to placentally derived endothelial disturbing factors like lipid peroxides and trophoblastic components as possible contributors for pathogenesis of PIH. Thus assessment of blood lipids may be helpful in preventions of complications in $\mathrm{PIH}$.

Key Words: Bloodlipids, PIH, Dyslipidemia, Triglycerides, Low Density Lipoprotiens, High Density Lipoprotiens.

\section{INTRODUCTION}

Pre-eclampsia, a non cancel convulsive form of pregnancy induced hypertension accounts for a significant proportion of maternal and fetal morbidity and mortality ${ }^{1}$. Over 100,000 women develop eclampsia per year. Eclampsia contributes $16 \%$ of maternal mortality on a national basis which is equivalent to about 4500 maternal death in one year. The risk of developing eclampsia appears to be greater in women who have family history of essential hypertension and their may also be a relationship between risk of preeclampsia and the metabolic syndrome ${ }^{2}$. Pre-eclampsia when complicated with convulsion is called eclampsia. The disorder complicates approximately 5 to 7 percent of pregnancies ${ }^{3-5}$. Severe PIH is associated with substantial risk for the foetus these include intrauterine growth restriction death and prematurity with attendant complications where as the mother is at risk of renal failure, pulmonary edema, stroke and death. Despite considerable 
research the cause or causes of pre-eclampsia remain unclear and there are no clinically useful screening tests to identify women in whom it will develop ${ }^{6}$. Early pregnancy dyslipidemia is associated with an increased risk of severe $\mathrm{PIH}^{7}$. The association of alteration of serum profile in pregnancy induced hypertension is well documented. In $\mathrm{PIH}$ patient an abnormal lipid profile is known to be strongly associated with atherosclerotic changes and direct effect on endothelial dysfunction. The most important feature in toxaemia of pregnancy in hypertension which is supposed to be due to vasospastic phenomenon in kidney, uterus, placenta and brain $^{8}$. Altered lipid synthesis leading to decrease in PGI2: TXA2 ratio is also supposed to be important way of pathogenesis in PIH. Abnormal lipid metabolism seems important in pathogenesis of $\mathrm{PIH}^{9}$.

Objective: To analyse the lipid profile values in Pregnancy Induced Hypertension patient.

Need of Study: Simple measurement of serum lipid parameters may be of good predictive value in toxaemia of pregnancy, avoiding the costly endocrinal investigations. The assessment of blood lipids may be helpful in prevention of complications in $\mathrm{PIH}$.

Study Period: 01 Nov. 2017 to 30 April 2018.

Sample size: 60 pregnant women of 3rd trimester with $\mathrm{PIH}$.

Methodology- Random blood sugar samples were taken from 60 pregnant patients with Pregnancy Induced Hypertension (PIH)

The samples were subjected to analysis of lipid profile.
Specimen- Freshly collected plasma. Anticoagulant used was EDTA.

Procedure -The lipid profiles of the samples were determined using a semiautomated analyser.

Study Design: Case Control Study.

\section{Inclusion Criteria}

Pregnant women in the third trimester diagnosed as PIH with no other associated complications.

\section{MATERIALS \& METHODS}

The study was performed in the department of biochemistry of medical college and hospital, JMC Jhalawar. All subjects were in age group of 18-35 years with low socio-economic status and dietary habits. They were not abstained from smoking and alcoholism.

No subject of PIH was suffering from any acute or chronic illness during study nor they had any post history of cardiac, renal, hepatic dysfunction or dyslipidaemia.

In PIH all patients were studied who had BP more than $140 / 90 \mathrm{~mm}$ of $\mathrm{Hg}$, proteinuria, oedema in third trimester of pregnancy.

Data collection technique: Study was performed in department of Biochemistry in JMC Jhalawar. Blood sample drawn from all subjects at the time of admissions and analyzed for serum triglycerides (TG), serum LDL, serum VLDL and serum HDL. Data were statistically analyzed by student's " $t$ " test and significance was expressed in term of " $P$ " value.

Table 1: Following Reagents were used for determination of the lipid values.

\begin{tabular}{|l|l|}
\hline Lipid Value & Reagents \\
\hline Total Cholesterol & Cholesterol Oxidase, Peroxidase \\
\hline HDL Cholesterol & Phosphotungstate / Magnesium precipitation \\
\hline LDL Cholesterol & Catalase / cholesterol esterase / cholesterol oxidase \\
\hline Triglycerides & Glycerol Phosphate oxidase/ Peroxidase \\
\hline
\end{tabular}


Dr. Nanu Ram Jat et al., Journal of Biomedical and Pharmaceutical Research

Table: 2 Reference values of the lab

\begin{tabular}{|l|l|}
\hline Lipid Value & Reference values \\
\hline Total Cholesterol & $125-200 \mathrm{mgs} / \mathrm{dl}$ \\
\hline HDL Cholesterol & $30-65 \mathrm{mgs} / \mathrm{dl}$ \\
\hline LDL Cholesterol & $85-130 \mathrm{mgs} / \mathrm{dl}$ \\
\hline Triglycerides & $25-200 \mathrm{mgs} / \mathrm{dl}$ \\
\hline VLDL & $05-40 \mathrm{mgs} / \mathrm{dl}$ \\
\hline
\end{tabular}

\section{RESULTS}

The data were intended in Ms Excel and we find out the mean and SD of lipid profile in PIH patients and we show that:

Table 3: Mean and SD of lipid profile in PIH patients

\begin{tabular}{|l|l|}
\hline Parameters (mg/dl) & Mean \pm SD \\
\hline Mean HDL level & $47.6 \pm 16.6$ \\
\hline Mean TG & $293.46 \pm 143.96$ \\
\hline Mean LDL & $151.06 \pm 72.71$ \\
\hline Mean VLDL & $53.83 \pm 26.15$ \\
\hline
\end{tabular}

Table 4: Comparison of Blood Lipids in PIH Patients with Their Standard Values.

\begin{tabular}{|l|l|l|l|l|}
\hline $\begin{array}{l}\text { Parameters } \\
\text { (mg/dl) }\end{array}$ & $\begin{array}{l}\text { Normal Value } \\
\text { (mg/d) }\end{array}$ & $\begin{array}{l}\text { Number of } \\
\text { Patients }\end{array}$ & $\begin{array}{l}\text { Percentage of } \\
\text { Patients (\%) }\end{array}$ & Mean +/- SD \\
\hline Triglycerides & $40-150$ & $\begin{array}{l}\text { Low-0 } \\
\text { Normal-8 } \\
\text { High-52 }\end{array}$ & $\begin{array}{l}\text { Low-0 } \\
\text { Normal-13.3 } \\
\text { High-86.6 }\end{array}$ & $293.46 \pm 143.96$ \\
\hline HDL Cholesterol & $35-75$ & $\begin{array}{l}\text { Low-8 } \\
\text { Normal-48 } \\
\text { High-4 }\end{array}$ & $\begin{array}{l}\text { Low-13.3 } \\
\text { Normal-80 } \\
\text { High-6.7 }\end{array}$ & $47.6 \pm 16.67$ \\
\hline $\begin{array}{l}\text { VLDL } \\
\text { Cholesterol }\end{array}$ & $2-30$ & $\begin{array}{l}\text { Low-0 } \\
\text { Normal-8 } \\
\text { High-52 }\end{array}$ & $\begin{array}{l}\text { Low-0 } \\
\text { Normal-13.3 } \\
\text { High-86.6 }\end{array}$ & $53.83 \pm 26.15$ \\
\hline LDL Cholesterol & $80-175$ & $\begin{array}{l}\text { Low-8 } \\
\text { Normal-32 } \\
\text { High-20 }\end{array}$ & $\begin{array}{l}\text { Low-13.3 } \\
\text { Normal-53.3 } \\
\text { High-33.3 }\end{array}$ & $151.06 \pm 72.71$ \\
\hline
\end{tabular}

*standard values in normal females, reference- Biochemistry Lab of JMC/ Reg. No. 318/JPR/2007-08

\section{DISCUSSION}

- In this study we investigate the role of lipid profile in PIH patients.

- $\quad$ Based on the reports of our PIH patients from the Biochemistry lab of Jhalawar medical college we found that:

- TG was increase in $86.6 \%$ of PIH patients. $\mathrm{HDL}$ was normal in $80 \%$ and decreased in $13.3 \%$
- $\quad$ LDL was increased in $33.3 \%$ and normal in $53.3 \%$

- VLDL was increased in $86.6 \%$ in $\mathrm{PIH}$ patients.

- TG: HDL ratio increased significantly in PIH patients Thus assessment of blood lipids may be helpful in prevention of complication in $\mathrm{PIH}$. The principle modulator of hypertriglyceridemia is oestrogen as pregnancy 
associated with hyperestrogenemia, oestrogen induced hepatic biosynthesis of endogenous triglyceride which is carried out by $\operatorname{VLDL}^{10}$.

Increased TG found in PIH is likely to be deposited in predisposed vessels such as uterine spiral arteries and contributes to the endothelial dysfunctions and both directly and indirectly through generation of small dense $\mathrm{LDL}^{11}$. This hypertriglyceridemia may be associated with hypercoagulability ${ }^{12}$.

In present study, no significant alteration in total cholesterol level could be observed and third trimester of normal pregnancy in any of the groups. These findings are similar to Satter et $\mathrm{al}^{13}$. However, others have found significant increase in serum total cholesterol in toxaemia of pregnancy. ${ }^{13,14}$

In our study, significant decreases in HDL were observed in severe PIH (PE \& E) pregnant women. Estrogen is responsible for induction of TG and HDL and suppression of serum LDL and estrogen level falls in severe PIH (PreEclampsia). ${ }^{15}$ The low level of HDL in preeclampsia is however not only because of hypoestrogenemea but also due to insulin resistance ${ }^{16}$.

Findings reported in this study suggest that the women who develop pre-eclampsia and eclampsia have disturbed lipid profile due to abnormal lipid metabolism, increased TG level and delayed TG clearance and high blood pressure are reason for the development of the pre-eclampsia and eclampsia.

So the need of lipid profile in early PIH patients may help in developing strategies for prevention and early diagnosis of preeclampsia and eclampsia.

\section{REFERENCES}

1. Vanderjagt DJ, Patel RJ, El-Nafaty AU, Melah GS, Crossey MJ, Glew RH. High density lipoprotein and homocysteine levels correlate inversely in preeclamptic women in northern Nigeria. Acta Obstet Gynaecol Scand. 2004; 83(6);536-42
2. Packer CS. Biochemical markers and physiological parameter as indices for identifying patients at risk of developing preeclampsia. J Hypertens. 2005;23: (1) 45-6

3. Jimenez $D M$, Pocovi $M$, Ramon-Cajal J, Romero MA, Martinez H, Grande F. Longitudinal study of Plasma Lipids and Lipoprotein cholesterol in normal pregnancy and peuperium. Gynaecol Obstet Invest. 1988;25 (3): 158-64

4. Dutta DC. Hypertensive Disorders in pregnancy. $6^{\text {th }}$ Edition Hiralal K. editor. In: Text Book of Obstetrics. New Central Book Agency Kolkata, India; 2005. P. 222-223

5. Nahar S. Begum S, Yasnur S, Rasul CH. Use of misoprostol for induction of labour in unfavorable cervix in eclampsia. Pak J Med Sci. 2004:20 (3):181-185

6. Caren G., Solomon, Seely EW. Preeclampsia searching for cause. New Eng J Med. 2004:350 (7):641-2

7. Enquobahrie $\mathrm{DA}$, Williams $\mathrm{MA}$, Butler $\mathrm{CL}$, Frderick IO, Millar RS, Luthy DA. Maternal Plasma Lipid concentration in early pregnancy and risk of preeclampsia. Am J Hypertens. 2004:17 (7): 574-81

8. Dutta DC. Hypertensive Disorders in pregnancy, $5^{\text {th }}$ Edition, Konar HL editor. In: Text Book of Obstetrics. New Central Book Agency Kolkata, India; 2001. P. 234-55

9. Robson, SC. Hypertension and renal disease in pregnancy. $6^{\text {th }}$ Edition. Edmonds DK. editor. In: Dewhurst's Textbook of Obstetrics and Gynaecology for Postgraduates. Blackwell Science, NewYork; 1999. P 167-69

10. Glueck CJ, Fallet RW, Scheel D. Effects of oestrogenic compounds on triglyceride kinetics. Metabolism. 1975; 24: 537-45

11. Sattar N, Bendomir A, Berry C, Shepherd J, Greer IA, Packard CJ. Lipoprotein sub fraction concentrations in preeclampsia pathogenic parallels to atherosclerosis. Obstet Gynaecol. 1997; 89 (3):403-8 
Dr. Nanu Ram Jat et al., Journal of Biomedical and Pharmaceutical Research

12. Kokia E, Barkai G, Reichman B, Segal P, Goldman B, Mashiach S. Maternal serum lipid profile in pregnancies complicated by hypertensive disorders. J Perinat Med. 1990;18 (6):473-8

13. Hubel CA, Lyall F. Weissfeld L, Gandley RE, Roberts JM, Small low-density lipoproteins and vascular cell adhesion molecule-I are increased in association with hyperlipidemia in preeclampsia. Metabolism 1998; 47 (10):1281-8

14. Adegoke OA, lyare EE, Gbenebitse SO, Fasting Plasma Glucose and cholesterol levels in pregnant Nigerian women. Niger Postgrad Med J. 2003; 10(1):32-6
15. Bradley R, Crook D. Pregnancy, Oral Contraception and hormone replacement therapy. In. Textbook of Clinical Biochemistry Metabolic and Clinical aspects. Marshall WJ. Bangert SK, editors. $1^{\text {st }}$ Edition, Churchill Livingstone, London, 1995, p.413-22

16. Kaaja R, Tirkkanen MJ, Viinnkka L, Ylikorkala O. Serum lipoproteins, insulin and urinary prostanoid metabolites in normal and hypertensive pregnant women. Obstet Gynaecol 1995; 85(3):3536. 